\title{
Blood glucose level of white rats (Rattus norvegicus) after giving catfish biscuit (Pangasius hypothalmus)
}

\author{
Hidayaturrahmah ${ }^{1}$, Heri Budi Santoso ${ }^{1}$, Ridha Aulia Rahmi ${ }^{1}$, Dewi Kartikasari ${ }^{1}$ \\ ${ }^{1}$ Department of Biology, Faculty of Mathematics and Natural Sciences, lambung Mangkurat University, \\ Banjarbaru 70714 Indonesia
}

\begin{abstract}
Glucose is an important carbohydrate which is more absorbed into the bloodstream as glucose and other sugar is changed into glucose in the liver. Blood glucose level is closely related to diabetes mellitus. Diabetes mellitus is a disease that arises in a person which is indicated by the presence of blood glucose levels exceeding normal (hyperglycemia) due to the deficiency of the insulin hormone in the body. The design of this research was using RAL with 24 male rats that divided into 6 treatments which were normal with the giving of $\mathrm{Na}-\mathrm{CMC} 0.5 \% 1 \mathrm{~mL} / 200$ gram $\mathrm{BB}$, negative with the giving of $\mathrm{Na}-\mathrm{CMC} 0.5 \% 1 \mathrm{~mL} / 200$ gram $\mathrm{BB}$, positive with the giving of glibenclamide of $0.45 \mathrm{mg} / \mathrm{kg}$ $\mathrm{BB}$ and 3 other treatments by giving catfish biscuit (Formula A, Formula B, and formula C) with 4 replications. All treatments were injected with monohydrate alloxan at a dose of $150 \mathrm{mg} / \mathrm{kg} \mathrm{BW}$, except for the normal treatment. The results showed that the formulation of catfish biscuit can lower the blood glucose level of white rats. The composition of biscuit with formula $\mathrm{C}$ has the highest decreasing percentage which was $80.20 \%$ to the blood glucose level of white rats.
\end{abstract}

\section{Introduction}

Glucose is an important carbohydrate which is more absorbed into the bloodstream as glucose and other sugar is changed into glucose in the liver. Glucose is also the main fuel in the body tissues and has the function to generate energy. Blood glucose level is closely related to diabetes mellitus [1]. Diabetes mellitus is a disease that arises in a person which is indicated by the presence of blood glucose levels exceeding the normal level (hyperglycemia) due to the deficiency of the insulin hormone in the body. If the disease is uncontrolled or the patient is unaware of the disease, there will be various fatal chronic complications [2]. Increasing the prevalence of diabetes mellitus in Indonesia can cause negative impact which is the decreasing of human resources (HR) due to this chronic disease and also in the case of medication, it is not cheap because the patient must consume drugs in a long time.

One symptom that is often found in diabetes mellitus patients is polyphagia that is a condition of having an appetite which increases but the patient losses his/her weight [3]. The existence of this appetite affects people with diabetes mellitus to consume food besides the staple food, in this case, it is by consuming biscuit. The biscuit that is circulating in the public is not given by vegetable or animal foods and nutritional content that is beneficial to health. Moreover, dietary factor becomes the main key to diabetes mellitus prevention and treatment. One alternative that can be used is by consuming functional foods that are proven to help to keep the blood glucose level at the normal level [4].

Based on that explanation, it is necessary to find out the antidiabetic biscuits that have relatively low side effects, cheap prices, easy to obtain, and derived from animal extracts, and one of them derived from catfish extract. Catfish contain various components that are very beneficial for the health of the body which are minerals, vitamins, and omega 3 fatty acids that are very beneficial to human health. The catfish have highfat content and are a very good source of unsaturated fatty acids, including omega 3 fatty acids that have a positive function for human health. This research was previously published in RJPBCS with the use of catfish extract in the form of oil.

This study aims to determine the effect of catfis $h$ biscuit on blood glucose level of white rats and determine the formula of catfish biscuit that is effective toward blood glucose level.

\section{Materials and Methods}

\subsection{Materials and equipments}

Materials used in this study were catfish, aquadest, alloxan, Na-CMC $0.5 \%$, glibenclamide, wheat flour, eggs, margarine and animal test that was used as the object of this research which was male white rat as many as 24 Wistar strains with 150-200 grams weight and 5-6 months old.

The tools used in this research were cage, drink bottle, scale, large tray, stirrer, printer, oven, and Blood Glucose Test Meter.

\subsection{Methods}

\subsubsection{Catfish Filtrate Making}

The method used was steam for 90 minutes with \pm 10 $\mathrm{mL}$ aquadest addition. 


\subsubsection{Catfish Biscuit Making}

The biscuit was roasted in an oven at $160^{\circ} \mathrm{C}$ for 30 minutes.

\subsubsection{Test Animal Maintenance and Treatment}

The mice were first in acclimatization for 1 week. Acclimatization was intended to allow the test animal to adapt to the conditions of the test place. Rats were fed, drank, and put in the same cage intending to not affect the results and the rats were able to adapt to the conditions of test place (laboratory). The cage was equipped with a drinking bottle and was covered with chaff evenly and cleaned at least 2 times a week. The cage was placed in a ventilated room to regulate the air circulation and radiation system so that light and dark conditions respectively for over 12 hours.

\subsubsection{5\% Na-CMC Solution Making}

$0.5 \mathrm{~g} \mathrm{Na}-\mathrm{CMC}$ was weighed and fed into an Erlenmeyer containing $\pm 10 \mathrm{~mL}$ aquadest that had been heated. It was set aside for 15 minutes until it was obtained a transparent mass, then it was mixed until homogeneous. After that, Na-CMC solution was transferred to a 100 $\mathrm{mL}$ measuring flask and be sufficient volume with the aquadest to the tera mark (Darmawi, 2015). The provision of a $0.5 \% \mathrm{Na}-\mathrm{CMC}$ solution was done orally with a given dosage of $0.5 \mathrm{mg} / \mathrm{kg} \mathrm{BB}$ of rat (Annex 1).

\subsubsection{Glibenclamide Solution Making}

The $5 \mathrm{mg}$ weighed glibenclamide was then finely crushed, and dissolved in $1 \% \mathrm{Na}-\mathrm{CMC}$ solution in a 25 $\mathrm{mL}$ flask. The given dose to rats was $0.45 \mathrm{mg} / \mathrm{kg} \mathrm{BB}$ of rats (Appendix 1) (Siwaka, 2013).

\subsubsection{Alloxan Solution Making and Induction}

Alloxan solution is the monohydrate alloxan powder which was weighed as much as $0.5 \mathrm{~g}$ then dissolved with aquadest up to a volume of $10 \mathrm{~mL}$. The dissolved alloxan was injected immediately before any color change occurs. The given dose was $150 \mathrm{mg} / \mathrm{kg}$ BB of the rat by intraperitoneal injection.

\subsubsection{Treatment Giving and Blood Glucose Level Measurement}

The tested animal that had been fasted for 12 hours and measured its fasting blood glucose level then was given the food treatment (catfish biscuit) for about 5 gram per serving orally and dissolved in cold aquadest (Nissa \& Madjid, 2016) for 15 days with drink provision by using ad libitum way (unlimited) and balanced with standard feeding. The measurement was made 6 times on the first, third, sixth, ninth, twelfth, and the last measurement day was on the fifteenth day of the treatment (Fahri et al., 2005). The ways of blood glucose level measurement were as follows:

1. Rats' tail was cleaned and injured

2. Blood was taken using a glucometer strip

3. Blood glucose level result was awaited for 10 seconds

\subsubsection{Percentage Calculation of Blood Glucose Level Changes}

The percentage calculation of the blood glucose level decreasing was measured by the following formula: (Astuti, 2012).

$$
\% \text { Decreasing }=\frac{\text { First } B G L-\text { Final } B G L}{\text { First } B G L} \times 100 \%
$$

\subsection{Data Analysis}

The collected data was quantitative, including the level of the blood glucose level of the rats. The data were analyzed by using the Kolmogorov-Smirnov test to know the normality of the data distribution and Levene's Test to find out the homogeneity of the data variance. The obtained data were distributed into normal and homogeneous then it was followed by ANOVA test and real difference test (Duncan). The data which was not distributed into normal but homogeneous then transformed by Log, Ln, and SQRT and non-parametric test using the Kruskal-Wallis test was done and continued by Real Difference test (Duncan).

\section{Results and Discussion}

\subsection{Blood Glucose Level of White Rats}

Based on the results of statistical analysis, from the use of ANOVA test for the normal and homogeneous distribution and the use of Kruskall-Wallis test for the non-normal distributed but homogeneous and also continued by the use of the Real Difference test using Duncan test, the obtained result is that catfish biscuit giving have a significant effect on the blood glucose level of white rats. The level of the blood glucose level of catfish biscuit treatment is still within the normal range. The blood glucose normal level of white rat is recorded $50-135 \mathrm{mg} / \mathrm{dL}$. The average level of blood glucose $(\mathrm{mg} / \mathrm{dL})$ can be seen in Table 1. 
Table 1. The Average Value of Blood Glucose Level (mg/dL).

\begin{tabular}{cccccccc}
\hline \multirow{2}{*}{$\mathrm{P}$} & \multicolumn{7}{c}{ Days } \\
\cline { 2 - 7 } & 0 & 1 & 3 & 6 & 9 & 12 & 15 \\
\hline $\mathrm{N}$ & $167 \pm 33.66$ & $107 \pm 12.71^{\mathrm{a}}$ & $118 \pm 28.16^{\mathrm{a}}$ & $113 \pm 11.58^{\mathrm{a}}$ & $106 \pm 22.95^{\mathrm{a}}$ & $117 \pm 41.73^{\mathrm{a}}$ & $122 \pm 3.40^{\mathrm{a}}$ \\
& $397 \pm 55.19$ & $286 \pm 110.21^{\mathrm{bc}}$ & $307 \pm 55.72^{\mathrm{bc}}$ & $274 \pm 120.94^{\mathrm{bc}}$ & $415 \pm 147.21^{\mathrm{c}}$ & $405 \pm 147.25^{\mathrm{b}}$ & $335 \pm 122.56^{\mathrm{b}}$ \\
\hline+ & $465 \pm 174.41$ & $407 \pm 92.13^{\mathrm{c}}$ & $364 \pm 62.32^{\mathrm{c}}$ & $291 \pm 11.41^{\mathrm{c}}$ & $190 \pm 33.51^{\mathrm{ab}}$ & $137 \pm 7.94^{\mathrm{a}}$ & $92 \pm 8.04^{\mathrm{a}}$ \\
$\mathrm{A}$ & $472 \pm 96.27$ & $251 \pm 105.13^{\mathrm{b}}$ & $291 \pm 98.98^{\mathrm{bc}}$ & $270 \pm 120.3^{\mathrm{bc}}$ & $244 \pm 117.44^{\mathrm{b}}$ & $174 \pm 56.09^{\mathrm{a}}$ & $121 \pm 23.69^{\mathrm{a}}$ \\
$\mathrm{B}$ & $470 \pm 92.50$ & $373 \pm 75.84^{\mathrm{bc}}$ & $243 \pm 15.56^{\mathrm{bc}}$ & $136 \pm 15.53^{\mathrm{a}}$ & $167 \pm 20.25^{\mathrm{ab}}$ & $166 \pm 21.65^{\mathrm{a}}$ & $101 \pm 5.36^{\mathrm{a}}$ \\
$\mathrm{C}$ & $466 \pm 160.45$ & $266 \pm 129.99^{\mathrm{bc}}$ & $249 \pm 105.73^{\mathrm{b}}$ & $163 \pm 33.38^{\mathrm{ab}}$ & $128 \pm 21.40^{\mathrm{ab}}$ & $127 \pm 34.95^{\mathrm{a}}$ & $93 \pm 4.21^{\mathrm{a}}$ \\
\hline
\end{tabular}

* The figures that are followed by the same letter in the same column show no real difference $(\mathrm{P}>0.05)$, while the figures with different letters in the same column indicate the values are the real difference $(\mathrm{P}>0.05)$.

Information:

$\mathrm{P} \quad=$ Treatment

$\mathrm{N}=$ Normal treatment without alloxan induction and is only given $0.5 \% \mathrm{Na}-\mathrm{CMC}$

$$
\begin{array}{ll}
- & =\text { treatment with alloxan and } 0.5 \% \text { Na-CMC } \\
+ & =\text { treatment with alloxan and Glibenclamide } \\
\text { A } & =\text { Treatment with alloxan and F1 biscuit } \\
\text { B } & =\text { Treatment with alloxan and F2 biscuit } \\
\text { C } & =\text { Treatment with alloxan and F3 biscuit }
\end{array}
$$

Based on Table 10, it shows that on the $15^{\text {th }}$ day of the catfish biscuits giving with formula $\mathrm{A}, \mathrm{B}$, and $\mathrm{C}$, it is obtained that the blood glucose level of the rats is in the normal range. In formula A giving treatment, it is obtained that the blood glucose level is $121 \mathrm{mg} / \mathrm{dL}$, in formula $\mathrm{B}$ is $101 \mathrm{mg} / \mathrm{dL}$ and in the formula, $\mathrm{C}$ is 93 $\mathrm{mg} / \mathrm{dL}$.

The changes in the blood glucose level of white rats in all treatments after the fifteenth day with biscuit giving are presented in graphical form (Figure 1). The average graph of blood glucose level $(\mathrm{mg} / \mathrm{dL})$ in all treatments can be seen in Figure 1.

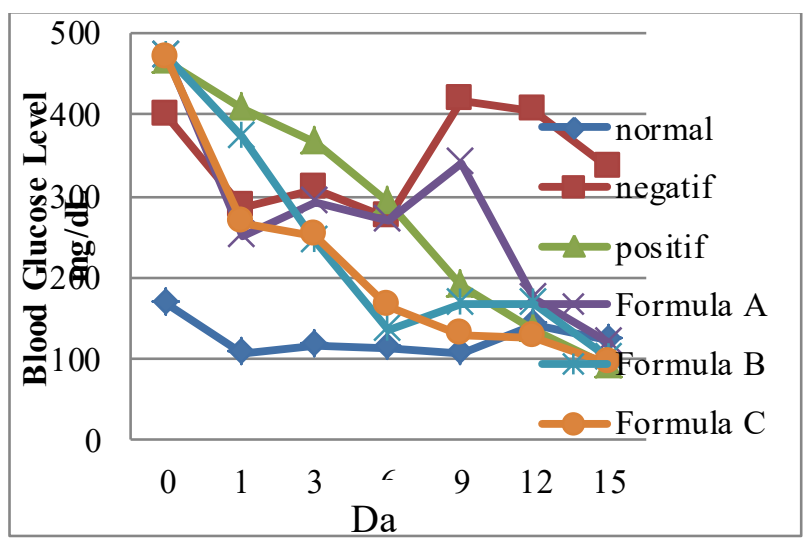

Figure 1. The Average Graph of Blood Glucose Level $(\mathrm{mg} / \mathrm{dL})$ in all Treatments.

\subsection{Changes Percentage of Blood Glucose Level from all Treatments}

The calculation of blood glucose level decreasing percentage aims to know the ability of the treatment in decreasing the blood glucose level which had been tested for 15 days (Appendix $4 \&$ Appendix 5). It can be also used to find out the decreasing percentage in all treatments that had been tested. The highest percentage of all treatments in formula $\mathrm{C}$ is similar to the positive

\begin{tabular}{|c|c|}
\hline Treatment & $\begin{array}{c}\text { Decreasing } \\
\text { Percentage }(\%)\end{array}$ \\
\hline Normal & 26.80 \\
\hline Negative & 15.62 \\
\hline Positive & 80.23 \\
\hline Formula A & 74.46 \\
\hline Formula B & 78.47 \\
\hline Formula $\mathrm{C}$ & 80.20 \\
\hline
\end{tabular}
control treatment. The calculation of the decreasing percentage can be seen in Table 2 below:

Table 2. The Decreasing Percentage of Blood Glucose Level

The treatment of catfish biscuit giving at various levels of the formula at the end of the whole observation shows the percentage of the effect that is comparable to the increase in the formula. Normal, negative, and positive control at the end of this treatment was $23.80 \%, 15.61 \%$, and $80.22 \%$. The catfish biscuit giving treatment that has the highest decreasing percentage was in formula $\mathrm{C}$ which was $80.20 \%$, while for formula $\mathrm{A}$ and formula $\mathrm{B}$ were $74.46 \%$ and $78.47 \%$.

\section{Conclusion}

It can be concluded that the catfish biscuit can affect the blood glucose level and can decrease the blood glucose level with the decreasing percentage as many as $80.20 \%$.

\section{References}

1. Amir, S.M.J., H. Wungouw \& D. Pangemanan. Blood Glucose Levels When in Patients with Type 2 Diabetes Mellitus in the Manado City Health Center. Journal of E-Biomedics (Ebm). 3 (1): 32-40 (2015)

2. Liahaq, A.M., Sudrajat \& Sudiastuti. 2015. Effectiveness Test of Karamunting Stems (Melastoma malabathricum L.) Against the Decrease in Diabetes Blood Glucose Levels of Mus 
(Mus musculus) Diabetes. Journal of East Borneo Science. 3 (3) (2015)

3. Azrimaidaliza. Nutrient intake and diabetes mellitus. Journal of Public Health. 6 (1): 36-41, (2011)
4. Hastarini, E., D. Fardiaz., H. E. Irianto \& S. Budijanto. Characteristics of Fish Oil from Siamese Patet Fish (Pangasius hypopthalmus) Filet Waste and Jambal Patang (Pangasius djambal). AGRITECH. 32 (4): 403-410, (2012) 